\title{
The use of InCaS model to identification and measuring of structural capital in small and medium enterprises
}

Ph. D. Elżbieta Izabela Szczepankiewicz Poznań University of Economics Department of Accounting

\section{Introduction}

The factors of structural capital are an important component of the market value of many business entities. For many years attempts have been made at developing uniform methods and models for identification and valuation of structural capital. A number of various financial and qualitative models have been developed globally for measuring this capital.

The author claims that it is "Intellectual Capital Statement - Made in Europe" (InCaS) that constitutes a particularly useful, complex tool for structural capital measuring. InCaS project initiated in 2006 by the European Commission as part of the EU's $6^{\text {th }}$ Framework Program. The aim of the project is to bring the global intellectual capital management and reporting experience to European SMEs. In Europe the InCaS project implementation in 25 pilot - SMEs. In the later period, the application of InCaS model in practice has gained interest of other individual entities in Europe. In Poland the InCaS project implementation in 5 pilot - SMEs, one of which

The use of InCaS model to identification and measuring of structural capital in small 
is BLOOMING Technologies Sp. z o.o. (Szczepankiewicz 2011, p. 186: Sikora 2007, p. 2, Szczepankiewicz 2012, p. 79). Author believes that such the InCaS model one could use to measurement of structural capital in newly created SMEs.

The purpose of the present work is to shows application of InCaS project for measuring and presenting structural capital in 25 pilot-SMEs in Europa, in this in 5 pilot-SMEs in Poland. The paper shows also practical application of InCaS concept for assess, to report and to develop the structural capital on the example of a modern company the industry of IT services in Poland: BLOOMING Technologies Sp. z o.o.

\section{Structural capital measuring with the use of InCaS model in European SMEs}

The InCaS concept is a modern complex tool for monitoring, control and improvement of intellectual capital management processes. It facilitates decision-making processes related to present and future functioning of a enterprises. It influences improvement of efficiency, market competitiveness of a business entity and may contribute to its gradual and sustainable development (Szczepankiewicz 2011, p. 186; Szczepankiewicz 2012, p. 80). The InCaS model mentions three intellectual capital elements which should be identified, measured and presented in statement $(\mathrm{InCaS} . .2008$, p. 25; Intellectual Capital Statement ..., 2008; Mertins K., Wen-Huan W., Will M. 2009): human capital, structural capital and relational capital. Structural capital (SC) provides infrastructural support for human capital and relational capital, by covering such aspects as (e.g. organisational structure, corporate culture, internal cooperation and knowledge transfer, management instruments, IT, databases, internal procedures and proces).

The concept of intellectual capital built using the above elements indicates that while staff and management (human capital) create and use knowledge, knowledge itself is multiplied by interactions within and outside the company (customer capital), and as a result institutionalized knowledge, procedures and databases (structural capital) owned by the company is generated. The three intellectual capital elements mentioned above are to some extent interdependent; they should cooperate in order to shape, as the result of their interaction and synergy achieved in effect, goodwill of a business entity and its competitive superiority on the market. (Szczepankiewicz, 2011, s. 185) Structural capital evolves and changes over time, and the most important part in these processes is played by internal co-working people and knowledge transfer, organisational structure, procedures, databases, corporate culture. 
The InCaS model has been was used to measurement of intellectual capital in many organizations in Europe. Author believes that such the InCaS model one could use to measurement of structural capital in newly created SMEs. Table 1 defines structural capital factors included in the analysis of the European SMEs participating in pilot studies (the InCaS Project 2006-2008).

\section{Table 1. Definitions of the structural capital factors included in the analysis of European SMEs participating in pilot studies}

\begin{tabular}{|c|c|c|}
\hline \multicolumn{2}{|r|}{ SC factor } & Definition \\
\hline SC-1 & $\begin{array}{l}\text { Customer } \\
\text { database }\end{array}$ & $\begin{array}{l}\text { Electronic and/or written agreements database, projects database, } \\
\text { markets database, customer profiles database and key persons } \\
\text { database. }\end{array}$ \\
\hline SC-2 & Expert database & $\begin{array}{l}\text { Competence center: employees' portfolios, subcontractors' portfolios, } \\
\text { cooperators' portfolios, managers' portfolios, as well as individual and/ } \\
\text { or electronic recruitment, mailing, networking and internet portals. }\end{array}$ \\
\hline SC-3 & $\begin{array}{l}\text { Organisational } \\
\text { structure } \\
\text { and internal } \\
\text { processes }\end{array}$ & $\begin{array}{l}\text { Fixed organisational structure in company: management board, finance, } \\
\text { legal department and administration. Variable organisational structure } \\
\text { in company: operational structure adjusted to product and services } \\
\text { provided. Internal procedures in company: procedures' specification, } \\
\text { responsibilities delegation and job descriptions. }\end{array}$ \\
\hline SC-4 & $\begin{array}{l}\text { Organisational } \\
\text { culture / } \\
\text { Corporate } \\
\text { culture / } \\
\text { Business } \\
\text { culture }\end{array}$ & $\begin{array}{l}\text { Organisational culture comprises all norms, rules and values, influencing } \\
\text { knowledge transfer, joint interaction and the working manner. } \\
\text { Compliance to laws and internal rules, etics kode and good manners. } \\
\text { Transparent rules of cooperation with subcontractors, cooperators, } \\
\text { customers, managers, employees and other partners. Rigorous obey } \\
\text { the norms and rules. Building of safety feeling e.g. insurance company } \\
\text { project, as well as company image/brands. }\end{array}$ \\
\hline SC-5 & $\begin{array}{l}\text { Optimisation } \\
\text { of project } \\
\text { management }\end{array}$ & $\begin{array}{l}\text { Cost optimisation in project, as well as project management tools (e.g. } \\
\text { MS Project) and communication tools (e.g. e-mail, Skype). Uniform email } \\
\text { addresses for managers, all employees and servers in company. Flexible } \\
\text { organisational, legal and cost, as well as flexible forms and methods of } \\
\text { project management adjusted to services provided. }\end{array}$ \\
\hline SC-6 & $\begin{array}{l}\text { Internal } \\
\text { cooperation } \\
\text { within the } \\
\text { organization / } \\
\text { knowledge and } \\
\text { skill transfer }\end{array}$ & $\begin{array}{l}\text { The manner how employees, organisational units and different hierarchy } \\
\text { levels exchange information and cooperate together. Organized transfers } \\
\text { of knowledge between the trainers and the departments executives. } \\
\text { Organisation of knowledge transfer between employees in operating units } \\
\text { and different levels in the hierarchy, and among between generations in } \\
\text { organisation. Definition of roles and responsibilities in organisation. Work } \\
\text { organisation: time schedules and clear responsibility. The structured way } \\
\text { of transfer of expert knowledge and experience (examples, case study) } \\
\text { internally and to partners. }\end{array}$ \\
\hline
\end{tabular}

The use of $\mathrm{InCaS}$ model to identification and measuring of structural capital in small and medium enterprises 


\begin{tabular}{c|l|l} 
SC-7 & $\begin{array}{l}\text { Management } \\
\text { instruments / } \\
\text { Leadership } \\
\text { instruments } \\
\text { and tools }\end{array}$ & $\begin{array}{l}\text { All managemnt instruments and tools, which support the efforts of the } \\
\text { leadership, as well as the information paths, which are incorporated in } \\
\text { the decision-making process. Ability to create an environment allowing } \\
\text { personal development. Bonuses and individual valorisation and other } \\
\text { incentives. Indicators, strategy assessment, budgeting, action plan, } \\
\text { business plan, formalising accounting documents. }\end{array}$ \\
\hline SC-8 & $\begin{array}{l}\text { Information } \\
\text { Technology \& } \\
\text { Explicit } \\
\text { Knowledge }\end{array}$ & $\begin{array}{l}\text { IT (hardware \& software applications including the content), environment } \\
\text { of networks, service center, internet, intranet, extranet and databases, } \\
\text { quality procedures security procedures and related equipments. Storing, } \\
\text { security and accessibility of common information. }\end{array}$ \\
\hline SC-9 & $\begin{array}{l}\text { Product/ } \\
\text { Process } \\
\text { innovation / } \\
\text { Methods } \\
\text { innovation }\end{array}$ & $\begin{array}{l}\text { New product and/or new services offered. Patents for new technologies. } \\
\text { Innovations of great importance for the future of the organization. Create } \\
\text { a project management plan. Optimisation and improvement of internal } \\
\text { procedures and all business processes and innovation management. } \\
\text { Implementing ISO, AFNOR and other norms in organization. }\end{array}$ \\
\hline SC-10 & Image/Brands & Building a positive image/brands of the company's market. \\
\hline
\end{tabular}

Source: Author's own study based on: InCaS...2008; p. 25; Ahlers 2007, p. 14;

Boronat et al. 2007, p. 13; Gradišar et al. 2007, p. 8; Guimard et al. 2007, p. 10; Insunza 2007, p. 11; Jamin 2007, p. 8; Kavka et al. 2007, p. 8; Kos et al. 2007, p. 8; Luthun 2007, p. 8; Meroño et al. 2007, p. 9; Šater et al. 2007, p. 8; Soumet 2007, p. 7; Stemberger et al. 2007, p. 8; Stollsteiner and Stollsteiner 2007, p. 8; Stüwe 2007, p. 8; Tolios 2007, pp.11-12; Ustaran et al. 2007, p. 11; Vélez et al., 2007, p. 9; Wissensbilanz 2007, p.15; Wissensbilanz 2007/08, pp.13-14; Kałużny et al. 2007, p. 13; Zyskowska and Seroczyńska 2007, p. 8; Sworowski et al. 2007, p. 8; Kowalewski et al. 2007, p. 9; Sikora 2007, p.7

The factors for structural capital included in the analysis of European SMEs participating in pilot studies are presented in table 2, as well as of Polish SMEs participating in European pilot studies are presented in table 3.

\section{Table 2. Factors for structural capital included in the analysis of European SMEs participating in pilot studies}

\begin{tabular}{l|c|c|c|c|c|c|c|c|c|c}
\cline { 2 - 9 } & \multicolumn{10}{c}{ SC factor } \\
\hline $\begin{array}{l}\text { The SMEs } \\
\text { in Europe }\end{array}$ & SC-1 & SC-2 & SC-3 & SC-4 & SC-5 & SC-6 & SC-7 & SC-8 & SC-9 & SC-10 \\
\hline $\begin{array}{l}\text { Poland } \\
\text { (5 SMEs) }\end{array}$ & $40 \%$ & $20 \%$ & $60 \%$ & $100 \%$ & $40 \%$ & $20 \%$ & $80 \%$ & $100 \%$ & $60 \%$ & $40 \%$ \\
\hline $\begin{array}{l}\text { Slovenia } \\
\text { (5 SMEs) }\end{array}$ & & & $100 \%$ & $100 \%$ & $100 \%$ & & $100 \%$ & $100 \%$ & $100 \%$ & \\
\hline $\begin{array}{l}\text { France } \\
\text { (5 SMEs) }\end{array}$ & & $20 \%$ & $40 \%$ & $60 \%$ & & $80 \%$ & $100 \%$ & $80 \%$ & $100 \%$ & \\
\hline
\end{tabular}




\begin{tabular}{l|c|c|c|c|c|c|c|c|c|c}
$\begin{array}{l}\text { Germany } \\
\text { (5 SMEs) }\end{array}$ & & & & $80 \%$ & & $100 \%$ & $60 \%$ & $100 \%$ & $100 \%$ & $20 \%$ \\
\hline $\begin{array}{l}\text { Spain } \\
\text { (5 SMEs) }\end{array}$ & & & $80 \%$ & $60 \%$ & & $100 \%$ & $20 \%$ & $100 \%$ & $80 \%$ & \\
\hline \multicolumn{1}{c|}{ Summary: } & $8 \%$ & $8 \%$ & $56 \%$ & $68 \%$ & $28 \%$ & $60 \%$ & $72 \%$ & $92 \%$ & $76 \%$ & $12 \%$ \\
\hline
\end{tabular}

Source: Author's own study based on: Ahlers 2007, p. 14; Boronat et al. 2007, p. 13;

Gradišar et al. 2007, p. 8; Guimard et al. 2007, p. 10; Insunza 2007, p. 11; Jamin 2007, p. 8; Kavka et al. 2007, p. 8; Kos et al. 2007, p. 8; Luthun 2007, p. 8; Meroño et al. 2007, p. 9; Šater et al. 2007, p. 8; Soumet 2007, p. 7; Stemberger et al. 2007, p. 8; Stollsteiner and Stollsteiner 2007, p. 8; Stüwe 2007, p. 8; Tolios 2007, pp.11-12; Ustaran et al. 2007, p. 11; Vélez et al. 2007, p. 9; Wissensbilanz 2007, p.15; Wissensbilanz 2007/08, pp.13-14; Kałużny et al. 2007, p. 13; Zyskowska and Seroczyńska 2007, p. 8; Sworowski et al. 2007, p. 8; Kowalewski et al. 2007, p. 9; Sikora 2007, p.7

Table 3. Factors for structural capital included in the analysis of Polish SMEs participating in European pilot studies

\begin{tabular}{|c|c|c|c|c|c|c|c|c|c|c|}
\hline \multirow[b]{2}{*}{ SMEs in Poland } & \multicolumn{10}{|c|}{ SC factors } \\
\hline & SC-1 & SC-2 & SC-3 & SC-4 & SC-5 & SC-6 & SC-7 & SC-8 & SC-9 & SC-10 \\
\hline $\begin{array}{l}\text { Blooming Techno- } \\
\text { logies Sp. z o.o. }\end{array}$ & Yes & Yes & Yes & Yes & Yes & & & Yes & & \\
\hline $\begin{array}{l}\text { Agencja Rozwoju } \\
\text { Regionalnego SA }\end{array}$ & Yes & & Yes & Yes & Yes & & Yes & Yes & Yes & \\
\hline ŻAK Sp. z o.o. & & & Yes & Yes & & & Yes & Yes & & Yes \\
\hline NEXBAU & & & & Yes & & Yes & Yes & Yes & Yes & \\
\hline Garten Polska & & & & Yes & & & Yes & Yes & Yes & Yes \\
\hline Summary: & $40 \%$ & $20 \%$ & $60 \%$ & $100 \%$ & $40 \%$ & $20 \%$ & $80 \%$ & $100 \%$ & $60 \%$ & $40 \%$ \\
\hline
\end{tabular}

Source: Author's own study based on: Sikora 2007, p.7-13; Kałużny et al. 2007, p. 13; Kowalewski et al. 2007, p. 9; Sworowski et al. 2007, p. 8; Zyskowska and Seroczyńska 2007, p. 8

The InCaS model proposes a number of auxiliary factors designed to support ongoing analyses of structural capital constituents by determining the current level of the target values. Such a comparison shows which corporate behaviors are the most desirable in the future. For the analysis of particular structural capital elements, quality ratios and financial ratios are used, including ratios based on costs. A detailed analysis of the indicators should concentrate on determining which structural capital components (Szczepankiewicz 2011, p. 187,

The use of $\mathrm{InCaS}$ model to identification and measuring of structural capital in small and medium enterprises 
Szczepankiewicz 2012, p. 82):

- must be regularly analyzed (action taken if and when required),

- do not require intervention (no immediate action necessary),

- must be stabilized and further monitored,

- have the largest room for improvement and should be further developed.

Sample analytical indicators for structural capital factors included in the analysis of European SMEs participating in pilot studies (the InCaS Project 20062008) are presented in table 4 .

Table 4. Analytical indicators for structural capital factors included in the analysis of European SMEs participating in pilot studies

\begin{tabular}{|c|c|c|}
\hline Factor & Indicator & Definition or unit of measurement \\
\hline \multirow[t]{2}{*}{ SC-1 } & Archive & $\begin{array}{l}\text { Set of files concerning cooperation records with former } \\
\text { and current customers (scale 1-5) }\end{array}$ \\
\hline & Receivers & Customers with close business relationship (\%) \\
\hline \multirow[t]{2}{*}{ SC-2 } & Recruitment instruments & $\begin{array}{l}\text { Available recruitment methods and used tools (data- } \\
\text { base, internet portals, institutions) (scale 1-5) }\end{array}$ \\
\hline & Actualisation & $\begin{array}{l}\text { Actualisation of employees data base (professional } \\
\text { experience, actual availability) (scale 1-5) }\end{array}$ \\
\hline \multirow[t]{4}{*}{ SC-3 } & Fixed part & $\begin{array}{l}\text { Number of existing procedures transparently defining } \\
\text { administration processes }(\%)\end{array}$ \\
\hline & Operational part & $\begin{array}{l}\text { Flexibility of operational structures for managing } \\
\text { service orders (scale 1-5) }\end{array}$ \\
\hline & Organisational units & Number of organisational units (number) \\
\hline & Hierarchy levels & Number of hierarchy levels (number) \\
\hline \multirow[t]{2}{*}{ SC-4 } & Succession plan for CEO & Existence of a succession plan for the CEO $(0 / 1)$ \\
\hline & Topic centred work groups & Number of Topic centred work groups \\
\hline \multirow[t]{2}{*}{ SC-5 } & Tools of projects & Assessment of used tools (scale 1-5) \\
\hline & Collaborative projects & Number of collaborative projects (number) \\
\hline \multirow[t]{5}{*}{ SC-6 } & Internal meetings & $\begin{array}{l}\text { Number of official cross-departmental meetings in the } \\
\text { last accounting year (number). }\end{array}$ \\
\hline & Collaborative projects & $\begin{array}{l}\text { Number of projects which were undertaken together } \\
\text { with other departments in the last accounting year } \\
\text { (number). }\end{array}$ \\
\hline & Succession regulations for CEO & Existence of a succession regulation for the CEO $(0 / 1)$ \\
\hline & $\begin{array}{l}\text { Succession regulations for other } \\
\text { top executives }\end{array}$ & $\begin{array}{l}\text { Number of top executives with succession regulation/ } \\
\text { Total number of top executives }(\%)\end{array}$ \\
\hline & Succession plan & Existence of a succession plan (number) \\
\hline
\end{tabular}




\begin{tabular}{l|l|l}
\multirow{4}{*}{ SC-7 } & Leadership instruments & Leadership instruments applied in organization \\
\cline { 2 - 3 } & Meetings with employees & Executives meetings (number) \\
\cline { 2 - 3 } & Appraisal interviews & Staff appraisal interviews (number) \\
\cline { 2 - 3 } & Incentive pay & Employees receiving incentive pay (number) \\
\hline \multirow{2}{*}{ SC-8 } & IT expenditure & IT expenditure (cost) \\
\cline { 2 - 3 } & $\begin{array}{l}\text { Expenditure for explicit knowl- } \\
\text { edge }\end{array}$ & Expenditure for explicit knowledge (cost) \\
\cline { 2 - 3 } & Internet & Access Internet (number) \\
\cline { 2 - 3 } & Intranet & Access Intranet (number) \\
\hline \multirow{2}{*}{ SC-9 } & New products & Number of new products (number) \\
\cline { 2 - 3 } & Sales of new products & Share of sales of new products (\%) \\
\cline { 2 - 3 } & Products in development & Number of products in development (number) \\
\cline { 2 - 3 } & Savings/innovation & Savings resulting from process improvement (\%) \\
\cline { 2 - 3 } & Formalized processes & Number of formalized processes (number) \\
\hline \multirow{2}{*}{ SC-10 } & $\begin{array}{l}\text { Opinion of the company expres- } \\
\text { sed by employees. }\end{array}$ & $\begin{array}{l}\text { Transparent operational rules, keeping company's } \\
\text { obligations, reliable for its employees) (scale 1-5) }\end{array}$ \\
\cline { 2 - 3 } & $\begin{array}{l}\text { Opinion of the company ex- } \\
\text { pressed by customers, business } \\
\text { partners and subcontractors }\end{array}$ & $\begin{array}{l}\text { Transparent operational rules, keeping company's } \\
\text { obligations, reliable for its business partners and other) } \\
\text { (scale 1-5) }\end{array}$ \\
\hline
\end{tabular}

Source: Author's own study based on: InCaS...2008; p. 38; Boronat et al. 2007, p. 31;

Gradišar et al. 2007, p. 18 Guimard et al. 2007, p. 21; Insunza 2007, p. 29; Jamin 2007, p. 20; Kavka et al. 2007, p. 18; Luthun, 2007 p. 19; Meroño et al. 2007, p. 23; Šater et al. 2007, p. 18; Stemberger et al. 2007, p. 18; Stollsteiner and Stollsteiner 2007, p. 19; Ustaran et al. 2007, pp. 22; Kałużny et al. 2007, p. 34; Zyskowska and Seroczyńska 2007, p. 18; Sworowski et al. 2007, p. 26; Kowalewski et al. 2007, p. 22; Sikora 2007, p.17-18

The InCaS model can also be used to develop other indicators adapted to the specific nature of an organization and its business. This model is a perfect tool for demonstrating which structural capital components have the largest room for improvement, and which of them should be developed, stabilized or further analyzed. The management obtains comprehensive information about actions necessary to stabilize or develop given structural capital components in various areas of capital.

Author believes that if such analyses are held regularly at predefined intervals (once a year), they can be supplemented with data from previous years in order to investigate progress rates.

The use of InCaS model to identification and measuring of structural capital in small and medium enterprises 


\section{Structural capital measuring in modern company operating in the industry of IT services in Poland}

The research for the purpose of this paper has been carried out on the basis of Intellectual Capital Statement of a Blooming Technologies Sp. z o.o. This enterprise operates in an advanced technologies industry in Poland, mainly in telecommunications and information technologies. Blooming Technologies provides professional project management, implementation and advisory services to its customers worldwide. Blooming Technologies gaining a position of a solid IT service provider to its customers. This company presents also continuous development of the structural resources and competence centre i.e. knowledge its employees, experts, consultants, partners and subcontractors. (Sikora 2007, p. 4)

Table 5 defines structural capital factors included in the analysis of the Blooming Technologies Sp. z o. o. under study.

\section{Table 5. Definition of the structural capital factors} in Blooming Technologies Sp z o.o.

\begin{tabular}{l|l|l}
\hline \multicolumn{2}{|c|}{ SC factors } & \multicolumn{1}{c}{ Definition } \\
\hline SC-1 & $\begin{array}{l}\text { Customer } \\
\text { database }\end{array}$ & $\begin{array}{l}\text { Customer profiles database, projects database, markets database, key } \\
\text { persons database, electronic and/ or written agreements database. }\end{array}$ \\
\hline SC-2 & Expert database & $\begin{array}{l}\text { Competence center: employees' portfolios, cooperators portfolios, } \\
\text { managers' portfolios, subcontractors' portfolios. Electronic recruitment, } \\
\text { mailing, internet portals, networking, individual recruitment. }\end{array}$ \\
\hline SC-3 & $\begin{array}{l}\text { Organisational } \\
\text { structure and } \\
\text { internal processes }\end{array}$ & $\begin{array}{l}\text { Fixed organisational structure: management board, administration, } \\
\text { finance, legal department. Variable structure: operational structure } \\
\text { adjusted to services provided. Internal procedures: procedures' } \\
\text { specification, job descriptions, responsibilities delegation. }\end{array}$ \\
\hline SC-4 & $\begin{array}{l}\text { Organisational } \\
\text { culture }\end{array}$ & $\begin{array}{l}\text { Transparent rules of cooperation with customers, employees and } \\
\text { partners. Set of rules. Rigorous obey the rules. Building of safety } \\
\text { feeling e.g. insurance and opinion of the company. }\end{array}$ \\
\hline $\begin{array}{l}\text { Optimisation } \\
\text { of project } \\
\text { management }\end{array}$ & $\begin{array}{l}\text { Cost optimisation in project performance, project management tools: } \\
\text { MS Project; communication tools: Skype. Uniform email addresses } \\
\text { for employees, servers. Flexible organisational, legal, cost and flexible } \\
\text { forms and methods of project management adjusted to services } \\
\text { provided. }\end{array}$ \\
\hline
\end{tabular}

Source: Sikora 2007, p.7 
Table 6 shows detailed results of identification and analysis of structural capital factors in the company under study.

Table 6. Summary of values of each factor in structural capital assessment in Blooming Technologies Sp.z 0.o. (\%)

\begin{tabular}{l|l|c|c|c|c|c}
\hline \multicolumn{2}{c|}{ SC factors } & Quantity & Quality & Systematic & $\begin{array}{c}\text { Mean } \\
\text { value }\end{array}$ & $\begin{array}{c}\text { Impro- } \\
\text { vement } \\
\text { potential }\end{array}$ \\
\hline SC-1 & Customer database & 30 & 70 & 30 & 43 & 57 \\
\hline SC-2 & Expert database & 60 & 75 & 25 & 53 & 47 \\
\hline SC-3 & $\begin{array}{l}\text { Organisational structure and } \\
\text { internal processes }\end{array}$ & - & 60 & 30 & 45 & 55 \\
\hline SC-4 & Organisational culture & - & 85 & 80 & 82 & 18 \\
\hline SC-5 & $\begin{array}{l}\text { Optimisation of project man- } \\
\text { agement }\end{array}$ & - & 80 & 80 & 80 & 20 \\
\hline
\end{tabular}

Source: Sikora 2007, p.13

The mean value of quantity, quality and systematic the basis for determining the room for improvement (development) of the measured structural capital factors. Strengths of Blooming Technologies are: optimisation of project management (SC-5) and organisational culture (SC-4). The organisational structure and internal processes (SC-3), as well as expert database (SC-2) and customer database (SC-1) are of the highest improvement potential and they need to be developed to enable achieving strategic objectives for this enterprise. In terms of "Quantity", expert database gained significant advantage over other structural capital factors. Organisational culture and optimisation of project management were rated on the highest level in terms of "Quality". The expert database and customer database were rated on a further position. In terms of "Systematic" the highest rates were given to organisational culture and optimisation of project management. Customer and expert database, as well as organisational structure and internal processes needs to be regularly strengthened. The customer database shows the highest improvement potential.

For the analysis of structural capital in the company under study, proper indicators were selected, taking into account needs and character of a business activity. For the analysis are used quality and financial indicators, including many indicators based on costs. Analytical indicators for structural capital

The use of $\mathrm{InCaS}$ model to identification and measuring of structural capital in small and medium enterprises 
factors in the company under study are presented in table 7.

Table 7. Analytical indicators for structural capital factors in Blooming Technologies Sp. $z$ o.o.

\begin{tabular}{|c|c|c|c|c|c|c|}
\hline $\begin{array}{c}\mathrm{SC} \\
\text { Factor }\end{array}$ & Indicator & Definition & Unit & $\begin{array}{l}\text { Current } \\
\text { Value }\end{array}$ & $\begin{array}{l}\text { Planned } \\
\text { Value }\end{array}$ & $\begin{array}{l}\text { Prog- } \\
\text { ress } \\
\text { rate }(\%)\end{array}$ \\
\hline \multirow[t]{2}{*}{ SC-1 } & Archive & $\begin{array}{l}\text { Set of files concerning cooperation } \\
\text { records with former and current } \\
\text { customers }\end{array}$ & $\begin{array}{l}\text { Scale } \\
1-5\end{array}$ & 5 & 5 & $100 \%$ \\
\hline & Receivers & $\begin{array}{l}\text { Customers with close business } \\
\text { relationship }\end{array}$ & $\%$ & 30 & 80 & $38 \%$ \\
\hline \multirow[t]{2}{*}{ SC-2 } & $\begin{array}{l}\text { Recruitment } \\
\text { instruments }\end{array}$ & $\begin{array}{l}\text { Available recruitment methods } \\
\text { and used tools (database, Internet } \\
\text { portals, institutions) }\end{array}$ & $\begin{array}{l}\text { Scale } \\
1-5\end{array}$ & 3,3 & 5 & $66 \%$ \\
\hline & $\begin{array}{l}\text { Actuali- sa- } \\
\text { tion }\end{array}$ & $\begin{array}{l}\text { Actualisation of employees data } \\
\text { base (professional experience, } \\
\text { actual availability) }\end{array}$ & $\begin{array}{l}\text { Scale } \\
1-5\end{array}$ & 2 & 5 & $40 \%$ \\
\hline \multirow[t]{2}{*}{ SC-3 } & Fixed part & $\begin{array}{l}\text { Number of existing procedures } \\
\text { transpa-rently defining administra- } \\
\text { tion processes }\end{array}$ & $\%$ & 20 & 80 & $25 \%$ \\
\hline & $\begin{array}{l}\text { Operational } \\
\text { part }\end{array}$ & $\begin{array}{l}\text { Flexibility of operational struc- } \\
\text { tures for managing service orders }\end{array}$ & $\begin{array}{l}\text { Scale } \\
1-5\end{array}$ & 5 & 5 & $100 \%$ \\
\hline SC-4 & Image & $\begin{array}{l}\text { Opinion of the company expressed } \\
\text { by employees, customers, business } \\
\text { partners and subcontractors }\end{array}$ & $\begin{array}{l}\text { Scale } \\
1-5\end{array}$ & 4 & 5 & $90 \%$ \\
\hline SC-5 & Tools & Assessment of used tools & $\begin{array}{l}\text { Scale } \\
1-5\end{array}$ & 3,75 & 5 & $75 \%$ \\
\hline
\end{tabular}

Source: Author's own study based on: Sikora 2007, p.17-18

The indicators analysis allows one to determine what action must be taken in order to stabilize or develop structural capital components structural capital in each analyzed area. Strengths of Blooming Technologies are: archive of customer database, flexibility of operational structures for managing service orders, as well as opinion (image) of this enterprise. Weaknesses of Blooming Technologies are: fixed procedures transparently defining administration processes and procedures of actualization of data base. 
Table 8 presents synthesized results of data analysis for the structural capital factors of Blooming Technologies and other SMEs in Poland (the InCaS Project 2006-2008).

Table 8. Values of each factor in structural capital of Polish SMEs participating in European pilot studies (\%)

\begin{tabular}{l|c|c|c|c|c}
\hline SC factor of the SMEs in Poland: & Quantity & Quality & Systematic & $\begin{array}{c}\text { Mean } \\
\text { Value }\end{array}$ & $\begin{array}{c}\text { Improve- } \\
\text { ment po- } \\
\text { tential }\end{array}$ \\
\hline Blooming Technologies Sp. z o.o. & 48 & 66 & 48 & 54 & 46 \\
\hline Agencja Rozwoju Regionalnego S.A & 58 & 43 & 50 & 50 & 50 \\
\hline ŻAK & 70 & 69 & 63 & 67 & 33 \\
\hline NEXBAU & 70 & 58 & 50 & 59 & 41 \\
\hline Garten Polska Mean value (\%): & $\mathbf{6 1}$ & $\mathbf{5 9}$ & $\mathbf{5 3}$ & $\mathbf{5 8}$ & $\mathbf{4 2}$ \\
\hline
\end{tabular}

Source: Author's own study based on: Kałużny et al. 2007, p. 24; Zyskowska and Seroczyńska 2007, p. 10; Sworowski et al. 2007, p. 16; Kowalewski et al., 2007, p. 15; Sikora 2007, p.12.

Quality of structural capital factors in Blooming Technologies were rated on the highest level (+7) in light mean value in SMEs in Poland. Quantity (-13) and systematic (-5) in Blooming Technologies shows the highest improvement potential.

\section{Concluding remarks}

Customer database, expert database, organisational structure and internal processes, organisational culture, optimisation of project management and other structural resources are concepts whose importance has recently grown, both in theory and in practice. The factors of structural capital have become an increasingly important component of the market value of many companies. The InCas model allows for estimating structural capital (structural values and structural resources). This model shows particular structural capital factors with their weak and strong points. It identifies areas with the most vital necessity of intervention in order to make the objectives set by the management of an

The use of $\mathrm{InCaS}$ model to identification and measuring of structural capital in small and medium enterprises 
organization possible to achieve. These enterprises that try to measure structural capital gain a number of benefits for business management. The key benefit is that the very preparation for drawing up a report on this type of capital requires one to rearrange, unify and/or improve corporate management principles in this area. A report on structural capital is also a perfect management and marketing tool.

\section{Summary}

The use of InCaS model to identification and measuring of structural capital in small and medium enterprises

Structural resources are an important component of the market value of many business entities. For many years attempts have been made at developing uniform methods and models for identification and valuation of structural capital. "Intellectual Capital Statement - Made in Europe" (InCaS) that constitutes a particularly useful, complex tool to assess, to report and to develop the intellectual capital and structural capital of an modern SME companies. The paper shows application of InCaS project for measuring and presenting structural capital in 25 pilot-SMEs in Europa, in this in 5 pilot-SMEs in Poland. The paper shows also practical application of InCaS concept for assess, to report and to develop the structural capital on the example of a modern company the industry of IT services in Poland - BLOOMING Technologies Sp. z o.o.

Keywords: Structural Resources, Structural Capital, Intellectual capital.

\section{Streszczenie}

Wykorzystanie koncepcji InCaS do identyfikacji i pomiaru kapitału strukturalnego $w$ małych $i$ średnich przedsiębiorstwach Zasoby strukturalne, podobnie jak kapitał ludzki, są ważnym składnikiem wartości rynkowej wielu podmiotów gospodarczych. Przez wiele lat podejmowano próby na opracowanie jednolitych metod i modeli w celu ich identyfikacji i wyceny. "Sprawozdanie z Kapitału Intelektualnego- Made in Europe" (InCaS) stanowi szczególnie przydatne, kompleksowe narzędzie do oceny, raportowania i rozwoju kapitału intelektualnego i strukturalnego nowoczesnych małych i średnich przedsiębiorstwach. W artykule przedstawiono zastosowanie projektu $\mathrm{InCaS} \mathrm{w}$ do pomiaru i prezentacji kapitału strukturalnego w 25 pilotażowych MŚP 


\section{Słowa}

kluczowe: $\quad$ zasoby strukturalne, kapitat strukturalny, kapitat intelektualny.

\section{References}

1. Ahlers R. (2007), Intellectual Capital Statement, Balance Technology Consulting $\mathrm{GmbH}$, Contrescarpe - Bremen, www.psych.lse.ac.uk/incas/ page38/page40/files/BALance.pdf (20.08.2012).

2. Boronat E., Toro M., Negrón R., Maguijarro J., Simón S. (2007), Intellectual Capital Statement 07.2006-06.2007, Technological Institute of Optics, Colour and Imaging, Technological Park -C/ Nicolás Copérnico, Paterna, www. psych.lse.ac.uk/incas/page38/page43/files/AIDO.pdf (20.08.2012).

3. Gradišar M., Žiger B., Pižmoht P. (2007), Bilanca intelektualnega kapitala (Intellectual Capital Statement 2007), Le-tehnika d.o.o., Kranj, www.psych. lse.ac.uk/incas/page38/page42/files/Le-tehnika.pdf(20.08.2012).

4. Guimard V., Meroc J.F., Lemaire C. (2007), Intellectual Capital Statement, Business \& Development Learning Institute - BDL Institute, Versailles, www.psych.lse.ac.uk/incas/page38/page39/files/BDL.pdf(20.08.2012).

5. Insunza M. (2007), Intellectual Capital Statement June 2006 - July 2007, SISTEPLANT S.L., Vizcaya, www.psych.lse.ac.uk/incas/page38/ page43/files/SISTEPLANT.pdf (20.08.2012).

6. InCaS: Intellectual Capital Statement - Made in Europe, European Intellectual Capital Statement Guideline (2008), developed by the InCaS Consortium,www.inthekzone.com/pdfs/Intellectual_Capital_Statement. pdf (20.08.2012).

7. Intellectual Capital Statement Quality Requirements (2008), developed by the Fraunhofer Institute for Production Systems and Design Technology (IPK), Berlin, European Commission.

8. Jamin B. (2007), Intellectual Capital Statement, BGME 2007, www.psych. lse.ac.uk/incas/page38/page39/files/ BGME. pdf.

9. Kałużny D., Bryzgalska J.A., Wiener A. (2007), Strategia Rozwoju ARR S.A. w Koninie, Bilans Wartości Niematerialnych 07.2006-06.2007, ARR SA, Konin, www.psych.lse.ac.uk/incas/page38/page41/files/ ARR.pdf (20.08.2012).

The use of $\ln \mathrm{CaS}$ model to identification and measuring of structural capital in small and medium enterprises 
10. Kavka D., Žiger B., Pižmoht P., Bilanca intelektualnega kapitala (Intellectual Capital Statement 2007), KAC d.o.o., Celje 2007, www.psych.lse.ac.uk/ incas/page38/page42/files/KAC.pdf (20.08.2012).

11. Kos B., Żiger B., Pižmoht P.: Bilanca intelektualnega kapitala (Intellectual Capital Statement 2007), INO Brežice d.o.o., Krška vas 2007, www.psych. lse.ac.uk/incas/page38/page42/files/INO.pdf(20.08.2012).

12. Kowalewski Z., Kowalewska J., Antczak J., Mikołajczyk R., Kwiatkowska E., Zasiadczyk E., Żabierek J., Jaworska K. (2007), Bilans Wartości Niematerialnych 07.2006-06.2007, GARTEN POLSKA - SIEĆ SKLEPÓW RETRO, Krzykosy, www.psych.lse.ac.uk/incas/page38/page41/files/ IGarten.pdf (20.08.2012).

13. Luthun J-F.: Intellectual Capital Statement,EBS 2007,www.psych.lse.ac.uk/ incas/page39/files/EBS.pdf (20.08.2012).

14. Meroño F., Sánchez S., Azor A., Pou R. (2007), Intellectual Capital Statement 07.2006-06.2007, SIDASA - Engineering Business Unit, Barcelona, www. psych.lse.ac.uk/incas/page38/page43/files/SIDASA.pdf (20.08.2012).

15. Mertins K., Wen-Huan Wang, Will M. (2009), InCaS: Intellectual Capital Management in European SME - Its Strategic Relevance and the Importance of its Certification, Fraunhofer IPK Berlin, Electronic Journal of Knowledge Management Volume 7 Issue 1.2009. www.psych.lse.ac.uk/incas/ page72/ page72. html(20.08.2012).

16. Šater S., Suhodolčan P., Žiger B. (2007), Bilanca intelektualnega kapitala (Intellectual Capital Statement 2007), Inter dyskont d.o.o., Ravne na Korolem, www.psych.lse.ac.uk/incas/page38/page42/files/Interdiskont.pdf (20.08.2012).

17. Sikora J. (2007), Intellectual Capital Statement 07.2006-06. 2007, BLOOMING Technologies Sp. z o.o., Warszawa. www.psych.lse.ac.uk/incas/page38/ page41/files/BLOOMING_V2.pdf(20.08.2012).

18. Soumet D. (2007), Intellectual Capital Statement, VMI - Zone Industrielle Nord, Montaigu, www.psych.lse.ac.uk/incas/page38/page39/files/ VMI.pdf (20.08.2012).

19. Stemberger J.P., Žiger B., Pižmoht P. (2007), Bilanca intelektualnega kapitala (Intellectual Capital Statement 2007), Glotta Nova d.o.o., Ljubljana, www. psych.lse.ac.uk/incas/page38/page42/files/Glotta\%20 Nova.pdf (20.08.2012).

20. Stollsteiner P. Stollsteiner I. (2007), Intellectual Capital Statement, Projiris, Montigny le Bretonneux, www.psych.lse.ac.uk/incas/page38/page39/ files/Projiris.pdf (20.08.2012).

21. Stüwe U. (2007), Intellectual Capital Statement, Malergeschäft Bethel v. Bodelschwinghsche Anstalten Bethel, Quellenhofweg - Bielefeld, http:/ / www.psych.lse.ac.uk/incas/page38/page40/files/Bethel. $\operatorname{pdf}(20.08 .2012)$. 
22. Sworowski M., Strauchmann M., Kolańska-Łoś J. (2007), Intellectual Capital Statement - Bilans Wartości Niematerialnych 2006-2007, NEXBAU, Karpicko, www.psych.lse.ac.uk/incas/page38/page41/ files/Nexbau. pdf (20.08.2012).

23. Szczepankiewicz E.I. (2011), The use of InCaS model for estimating the value of intellectual capital within an organization, Management, University of Zielona Góra, Zielona Góra.

24. Szczepankiewicz E.I. (2012), The use of InCaS model for estimating the value of human capital in future-oriented organizations, Human Resources Management \& Ergonomics, Vol.6, No 1/2012, http://frcatel.fri.uniza. sk/hrme/files/2012/2012_1_07.pdf. (20.08.2012).

25. Tolios G. (2007), Ergebnis-Präsentation Wissensbilanz (Intellectual Capital Statement 2006-2007), JRC Capital Management Consultancy \& Research, Berlin. Www.psych.lse.ac.uk/incas/page38/page40/files/JRC.pdf (20.08.2012).

26. Ustaran J.I., García J., Villamor I., Hernández R., Mc Hoyuela F., Esteve A. (2007), Intellectual Capital Statement 2006-2007, FORMACIÓN DIGITAL GTD,Sevilla, www.psych.lse.ac.uk/incas/page38/page43/files/FD. $\operatorname{pdf}(20.08 .2012)$.

27. Vélez F.S., Almagro P., Lavergne J.J. (2007), Intellectual Capital Statement 2007, VERTISUB S.L, Ripollet, www.psych.lse.ac.uk/incas/page38/ page43/files/VERTISUB.pdf (20.08.2012).

28. Wissensbilanz 2007, Beyers GmbH (2007) ,www.psych.lse.ac.uk/incas/ page38/page40/files/Bethel.pdf (20.08.2012).

29. Wissensbilanz 2007/08 (Intellectual Capital Statement 2007/2008, 01.07.200730.06.2008), PASS Stanztechnik AG, 2007/2008, www.psych.lse.ac.uk/ incas/page38/page40/ files/PASS08.pdf(20.08.2012).

30. Zyskowska M., Seroczyńska D. (2007), Intellectual Capital Statement - Bilans Wartości Niematerialnych, Żak Sp. z.o.o., Warszawa. www.psych.lse.ac.uk/ incas/page38/ page41/files/Zak.pdf (20.08.2012).

The use of InCaS model to identification and measuring of structural capital in small and medium enterprises 